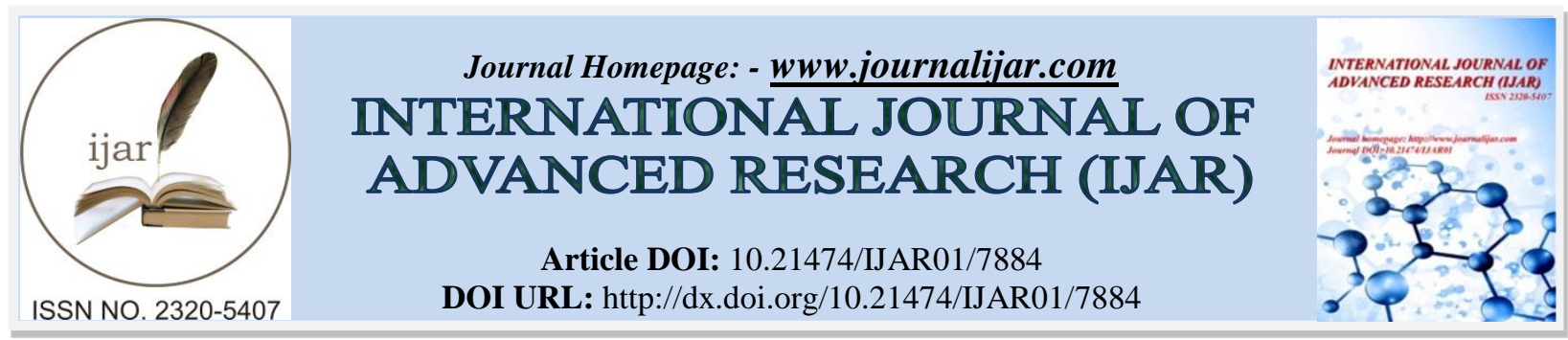

RESEARCH ARTICLE

\title{
MORPHOLOGICAL, PHYTOCHEMICAL AND ANTIBACTERIAL PROPERTIES OF AMORPHOPHALLUS SYLVATICUS (ARACEAE)
}

Raghavan Kavalan 1 , V. Abdul Jaleel ${ }^{2}$ and K.M. Gothandam ${ }^{3}$.

1. Jawahar Navodaya Vidyalaya, Bangalore Urban, Bagalur P.O., Karnataka. India 562149

2. Dept. of Post Graduate studies and Research in Botany, Sir Syed College, Taliparamba, Karimbam P.O., Kannur, Kerala, India, 670142. Ph: 944754140.

3. School of Bio Sciences and Technology, VIT University, Vellore, Tamil Nadu. India. 632014.

\section{Manuscript Info}

(........................

Manuscript History

Received: 10 August 2018

Final Accepted: 12 September 2018

Published: October 2018

Key words:

Araceae, Amorphophallus sylvaticus,

Phytochemical, Antibacterial,

Antioxidant,

\section{Abstract}

The morphological features, phytochemical properties, antioxidant and antibacterial properties of Amorphophallus sylvaticus, a member of the family Araceae belongs to the Sect. Raphiophallus was investigated. For chemical extraction, solvents hexane, methanol and water were used. Phytochemical screening revealed the presence of phenols and flavonoids in extracts of methanol and water. The presence of carbohydrates, reducing sugars, glycosides and saponins were confirmed in hexane extract. Tannins, anthraquinones, terpenoids and glycosides were detected in aqueous extract besides phenols and flavonoids. Among the three, methanol extract expressed maximum efficacy in DPPH radical scavenging assay while hexane and aqueous extract expressed relatively low radical scavenging property. All the three extracts showed good antibacterial property against the nine species of bacterial cultures studied. Hexane and methanol extract exhibited inhibition in maximum number of bacterial cultures compared to aqueous extract. High rate of inhibition was observed in hexane extract. The present study suggests that the corm of Amorphophallus sylvaticus have great potential as a natural source of antioxidant and has good antibacterial property.

Copy Right, IJAR, 2018,. All rights reserved.

\section{Introduction}

Plants of the genus Amorphophallus belongs to the family Araceae. About 200 species of Amorphophallus are distributed throughout the world and 20 species are reported from India (V. Abdul Jaleel et al., 2011). All the wild relatives of Amorphophallus except A. paeoniifolius are rare and sparsely distributed. Amorphophallus species are known to have a long history of use in tropical and subtropical Asia as a source of food, fodder and as traditional medicines and is a major ingredient in several herbal preparations. Tubers of Amorphophallus has also been used as antidote for snake bite by tribal's in certain villages of Rajasthan (Jain et al., 2005). It is also known that tubers of A. sylvaticus are being used for tooth ache in certain areas (E.Revathi and G.Rani, 2014). A few species such as Elephant foot yam (Amorphophallus paeoniifolius var. companulatus) are widely cultivated and used as vegetable. Many wild relatives of the genus Amorphophallus are traditionally used as medicine, fodder and in wine production (Hetterschield W. L. A and Ittenbach, S.,1996). The tuberous corms of Amorphophallus are reported to be used for 
treatment of piles, cysts and tumors (Ravikumar and Ved, 2004; Kavitha et al.,2011); acute rheumatism, abdominal tumors, boils, asthma and enlargement of spleen (Yusuf et al.,1994). It is believed that the therapeutic effect of medicinal plants is due to its biologically active compounds. A detailed study of this plant will help to identify the presence of various bioactive compounds responsible for its therapeutic effect as there is a need to develop functional food and medicines from phytochemicals of plant origin to avoid the use of hazardous synthetic products and to improve the status of human health and disease prevention.

Most of the Phytochemical and related studies conducted so far are in the genus are confined to only some of the widely available species like Amorphophallus paeoniifolius (Elephant Foot Yam - cultivated and wild) and A. commutatus varieties. Other species of the genus are unexplored due to its rare distribution and non-availability. Studies were carried out on Morphological, phytochemical and antibacterial properties of wild and indigenous plant A. commutatus var. wayanadensis (Arjun R Krishna et al., 2012), Phytochemical and anti-bacterial analysis of different species of Amorphophallus mainly A. commutatus (Sagarika Damle and Atul Kotian (2015), radical scavenging activity of $A$. commutatus (R. Kavita Krishna et al., 2012). Phenolic content and antioxidant capacity of A.commutatus and A.paeoniifolius (Shete C.C et al., 2015), Pharmacognostic evaluation and phytochemical analysis of A.paeoniifolius ( Yadu Nandan Dey and Ajoy Kumar Ghosh, ( 2010), Yadu Nandan Dey et al.(2012), P.Madhurima et al.(2012), Jyoti D. Vora et al.(2015), Firdouse S. Alam P. (2011), Manju Madhavan and Regi Raphel.K (2012), Morphology and taxonomy of Amorphophallus sylvaticus ( V.Abdul Jaleel et al., 2011) in the revision of Amorphophallus in India and Antimicrobial potential activity of Amorphophallus sylvaticus against oral microorganisms using seed extract (E. Revathi and G.Rani, 2014). The present study investigated the tuber extracts of Amorphophallus sylvaticus for its phytochemical constituents, antioxidant and anti- bacterial properties for the first time.

\section{Morphological Features}

The species of Amorphophallus exhibit variation in shape and size of tuber, petiole, spathe, spadix, and the individual female flowers. It is one of the most difficult genera of the family due to the short period of emergence of inflorescence and their relatively short active period of existence. The morphological similarity of the leaves of many species makes identification of the species with vegetative specimens difficult. 

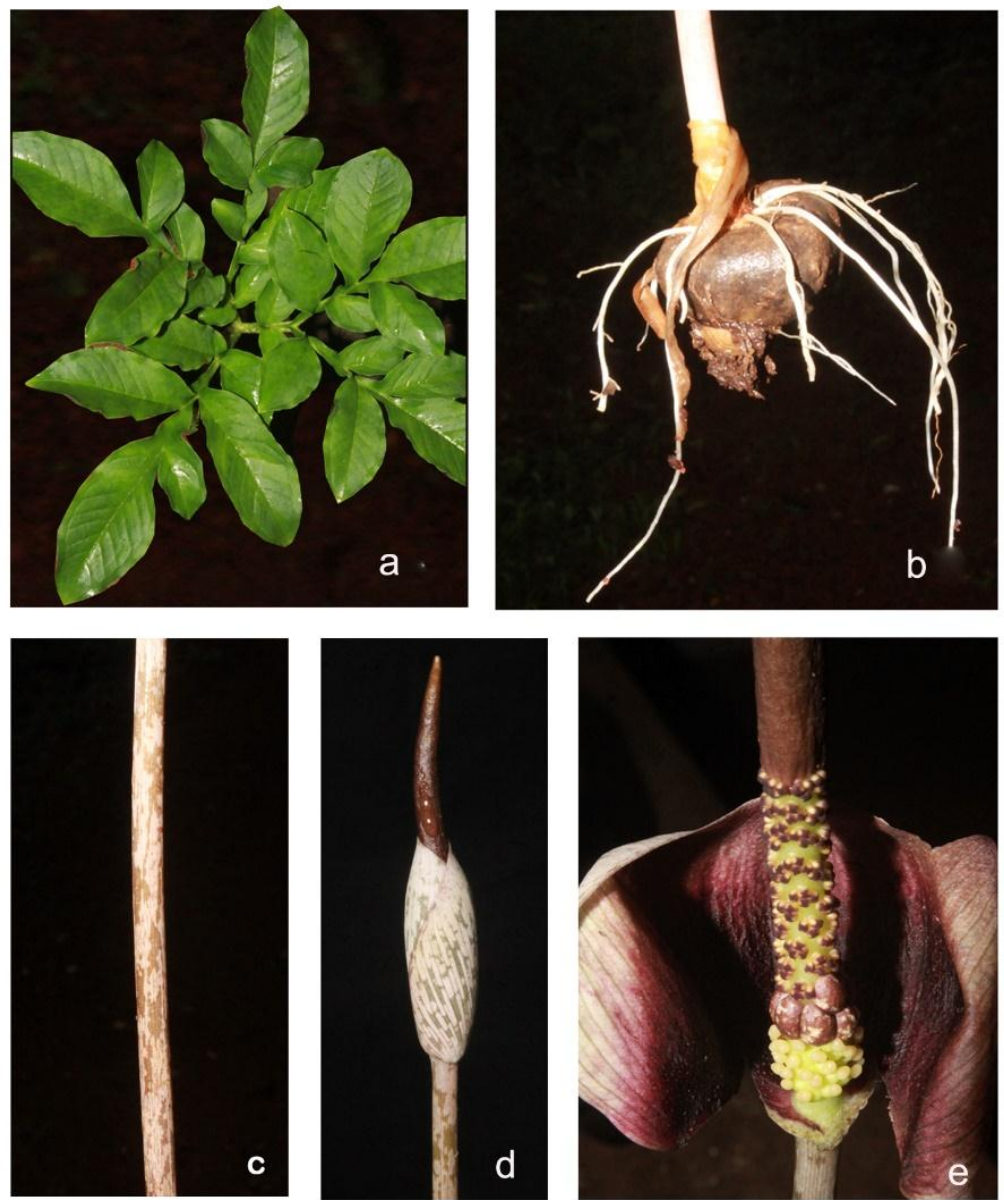

Figure.1:- Amorphophallus sylvaticus. a, A portion of petiole showing lamina; b.Tuber; c. A portion of petiole showing mottlings; d. Inflorescence; e. A portion of spadix cut open showing male and female flowers.

Tubers depressed sub-globose, 3-5.5 cm diam. and 1.5-3.0 cm thick in vegetative phase; 4.5-6 cm diam. and 3-4 cm in thick in reproductive phase; skin smooth, cream-coloured. Petiole smooth, 29-64 cm long and 0.5-1.5 cm diam. at the base, greenish with pale green ovate-elongate irregular blotches with white margin, and with minute mottling in between the blotches. Lamina 32-60 cm diam., leaflets glabrous, ovate-elliptic, lanceolate or linear lanceolate, 4.0$7.5 \mathrm{~cm}$ long and $2.5-3.5 \mathrm{~cm}$ broad, decurrent at the base, tip acute, or acuminate in the case of linear lanceolate leaflets, ventral side pale green, margin slightly undulate. Peduncle smooth, $35-50 \mathrm{~cm}$ long and $1 \mathrm{~cm}$ diam. at the base, identical with petiole in colour and pattern of blotches. Spathe ovate, 3.0-5.5 cm long and 4.0-6.5 cm broad, completely convolute and open at the top; pale pinkish or greenish-purple outside, purple and verrucose within. Spadix 5-6 times than the spathe, 14-21 cm long; stipitate; stipe 3-5 mm long, pale greenish; female zone 0.8-1.2 cm long, male zone 1.5-3.0 cm long; terminal spadix appendix ca.18 cm long. Female flowers densely arranged, ovary sub-globose, $2 \mathrm{~mm}$ long and $2 \mathrm{~mm}$ diam., 2-locular with single ovule in each locule; style short, 1-1.5 mm long, pale yellowish; stigma $1.5 \mathrm{~mm}$ broad, 2-lobed. Neuter flowers oblong-gibbous, 4-5 cm long, 3-4 mm diam., dark brown. Male flowers arranged in groups, each group with 2-5 flowers, each flower $1.2 \mathrm{~mm}$ long and $1.5 \mathrm{~mm}$ broad. Spadix appendix purplish. Berries usually 2 - seeded, scarlet when mature.

Phenology: Flowering: April-June; Fruiting: July-August.

\section{Materials and Methods}

The plant Amorphophallus sylvaticus were collected from the surrounding area of Vedanthangal Bird Sanctuary, Kancheepuram District, Tamil Nadu, India. The plant species were identified and authenticated by one of the author Dr. V. Abdul Jaleel, Department of Post Graduate Studies and Research in Botany, Sir Syed College, Taliparamba, 
Kannur, Kerala and was deposited in the Sir Syed College Herbarium and also maintained at the Aroid Home, Sir Syed College, Taliparamba, Kerala.

\section{Preparation of Extracts}

The tubers were properly washed followed by surface sterilization using $1 \%$ of sodium hypochlorite (Maina et al., 2010). The tubers were chopped into pieces, sun dried, and powered using an electric blender. Extraction was done by Soxhlet apparatus (Gennaro et al., 2008) using solvents viz: Hexane, methanol, and water in the increasing order of their polarity. The obtained solvent extracts were concentrated using vacuum distillation process and tāhe extracts were stored in refrigerator at $4^{\circ} \mathrm{C}$ (Ayvaz et al., 2008; Sultana et al., 2009).

\section{Bacterial Strains}

Nine species of human pathogenic bacteria obtained from the National Collection of Industrial Microorganisms (NCIM), Pune, India, and available with School of Bio Sciences and Technology, VIT University were used for the present study. The gram-negative bacterial species used for testing were Escherichia coli and Salmonella. The grampositive strains used are Bacillus cereus, Listeria monocytogenes, Bacillus coagulans, Streptococcus faecalis, Staphylococcus aureus, Bacillus circulans and Staphylococcus epidermis. These strains were preserved at $4^{\circ} \mathrm{C}$ in the nutrient broth as stock cultures and were sub-cultured for $24 \mathrm{hrs}$ at $37^{\circ} \mathrm{C}$ prior to use.

\section{Phytochemical Analysis}

Phytochemical tests were carried out on the Hexane, methanol and aqueous extract of plant materials using standard procedures (Trease and Evans, 1978; Edeoga et al., 2005). The analysis was done to test the presence of phytochemicals such as carbohydrates, (Molisch test), reducing sugars (Fehling's test), tannins (Ferric Chloride test), flavonoids (Shinoda test), steroids (Liebermann's -Burchard's test), alkaloids (Wagner's Test), anthraquinones (Borntrager's test), glycosides (Keller-Kiliani test), terpenoids(Salkowski Test), saponins (Frothing test) and phenols( Ferric Chloride test).

\section{Anti-bacterial Assay}

The anti-bacterial assay was performed on both gram positive and gram-negative bacterial species by well diffusion method (Onkar and Dhingra, 1995). The Petri plates were poured with approximately $25 \mathrm{ml}$ autoclaved nutrient agar media each. Using a micropipette, standardized inoculums $(0.1 \mathrm{ml})$ of $0.5 \mathrm{McFarland}$ turbidity standards, equivalent to $5 \times 10^{8} \mathrm{cfu} / \mathrm{ml}$ (Lopez-Brea et al., 2008) was aseptically spread on the surface of nutrient agar plate. After drying, four wells were punched on each plate using a sterile cork borer of $8 \mathrm{~mm}$ diameter (Bradshaw, 1992). $0.1 \mathrm{ml}$ of each extract (concentration of $100 \mathrm{mg} / \mathrm{ml}$ each) was pipetted into respective wells (Ayfer and Turgay, 2003). 10\% Dimethyl sulfoxide). Kanamycin is used as positive drug control. The Petri plates were incubated overnight at $37^{\circ} \mathrm{C}$ and the anti-bacterial activity was measured after $18 \mathrm{hrs}$ of incubation. The diameter of ZOI was also measured.

\section{Quantitative Analysis}

\section{DPPH Assay}

The DPPH assay was performed to determine the free radical scavenging potential of extract. $1 \mathrm{ml}$ of $0.2 \mathrm{mM} \mathrm{DPPH}$ in methanol was mixed with $4 \mathrm{ml}$ of different concentration of extracts and standards. The solution is mixed vigorously and incubated in darkness for 30min. The free radical (1,1-diphenyl-2-picryhydrazyl) which is absorbing UV-light at $517 \mathrm{~nm}$ will be reduced in the presence of antioxidant compound contained in the extract. This reaction will form a yellow molecule which will not absorb at the working wavelength. The more potential the extract is, the higher free radical scavenging i.e., the lower absorbance at $517 \mathrm{~nm}$ is measured.

The percentage of scavenging was calculated as follows:

$\%$ Scavenging $=(1-$ A sample $/$ A control $) \times 100$

Where A sample is absorbance measured in the presence of extract and A control is the one measured in absorbance of extract.

\section{Nitric Oxide Radical Scavenging Assay}

Nitric oxide scavenging activity of all the three extracts were determined. $1 \mathrm{ml}$ of $10 \mathrm{mM}$ sodium nitroprusside was mixed with $1 \mathrm{ml}$ of different concentration of extracts and standards and the mixture was incubated at $37^{\circ} \mathrm{C}$ for 150 min. After incubation $1 \mathrm{ml}$ of the mixture was taken out to which $1 \mathrm{ml}$ of Griess' reagent (1\% sulphanilamide and $0.1 \%$ naphthyl thylene diamine dihydrochloride in $2 \%$ o-phosphoric acid) was added and the absorbance were measured at $546 \mathrm{~nm}$. The procedure is based on the principle that, sodium nitroprusside in aqueous solution at 
physiological $\mathrm{pH}$ spontaneously generates nitric oxide which interacts with oxygen to produce nitrite ions. These nitrite ions can react with Griess' reagent and to form a chromophore absorbing at $546 \mathrm{~nm}$. Scavengers of nitric oxide compete with oxygen, leading to reduce the production of nitrite ions. The absorbance of the chromophore which was formed will be measured at $546 \mathrm{~nm}$ and will decrease in presence of extracts.

The percentage of scavenging was calculated as follows:

$\%$ Scavenging $=(1-$ A sample/A control $) \times 100$

Where A sample is the absorbance in the presence of extract and A control is the one measured I absence of extract.

\section{Results:-}

Table 1:-Phytochemical screening of Tuber extracts of Amorphophallus sylvaticus viz. Methanol, Hexane and water.

\begin{tabular}{|l|l|l|l|l|}
\hline Chemical constituent & Name of test & Hexane & Methanol & Water \\
\hline Carbohydrates & Molisch test & - & - & + \\
\hline Reducing sugar & Fehling's test & - & - & + \\
\hline Tannins & Ferric chloride test & - & + & - \\
\hline Flavonoids & Shinoda test & + & + & - \\
\hline Alkaloids & Wagner's test & - & + & - \\
\hline Anthraquinones & Borntrager's test & - & + & - \\
\hline Glycosides & Keller-Kiliani test & - & - & + \\
\hline Terpenoids & Salkowski test & - & + & - \\
\hline Saponins & Frothing test & - & - & + \\
\hline Fats and oils & Spot test & + & + & - \\
\hline Phenolics & Ferric chlorides test & + & + & + \\
\hline
\end{tabular}

+ indicate presence, - indicate absence.

Preliminary qualitative tests of the hexane, methanolic and aqueous extracts of Amorphophallus sylvaticus expressed the presence of different kinds of phytochemicals like tannins, alkaloids, anthraquinones, glycosides, phytotannins, terpenoids, saponins, phenolics, reducing sugars and carbohydrates. Preliminary result showed the presence of flavonoids in methanolic and hexane extract. Phenolics were present in all three extracts which indicated the potential antioxidant nature of the sample. The presence of tannins, flavonoids, alkaloids, anthraquinones, terpenoids, phenolics and fats and oils were confirmed in methanolic extract. Carbohydrates, reducing sugars, glycosides and saponins and phenolics were detected in aqueous extract.

\section{DPPH Assay}

DPPH radical scavenging activity is one of the most widely used method for screening the antioxidant activity of plant extract. Fig.1 shows the antioxidant activities of hexane, methanol and water extracts of Amorphophallus sylvaticus using the DPPH radical scavenging. $50-300 \mu \mathrm{g} / \mathrm{ml}$ of methanol extracts produces moderate to high DPPH radical scavenging. The highest DPPH activity was found in methanolic extract which is $96.817 \%$ which is almost similar to ascorbic acid reading of $95.33 \%$ whereas water and hexane extract shows almost similar activity as shown in the graph given below which is far less than methanolic extract. From this we can say that methanolic extract shows more scavenging activity and has as a good antioxidant potential. 


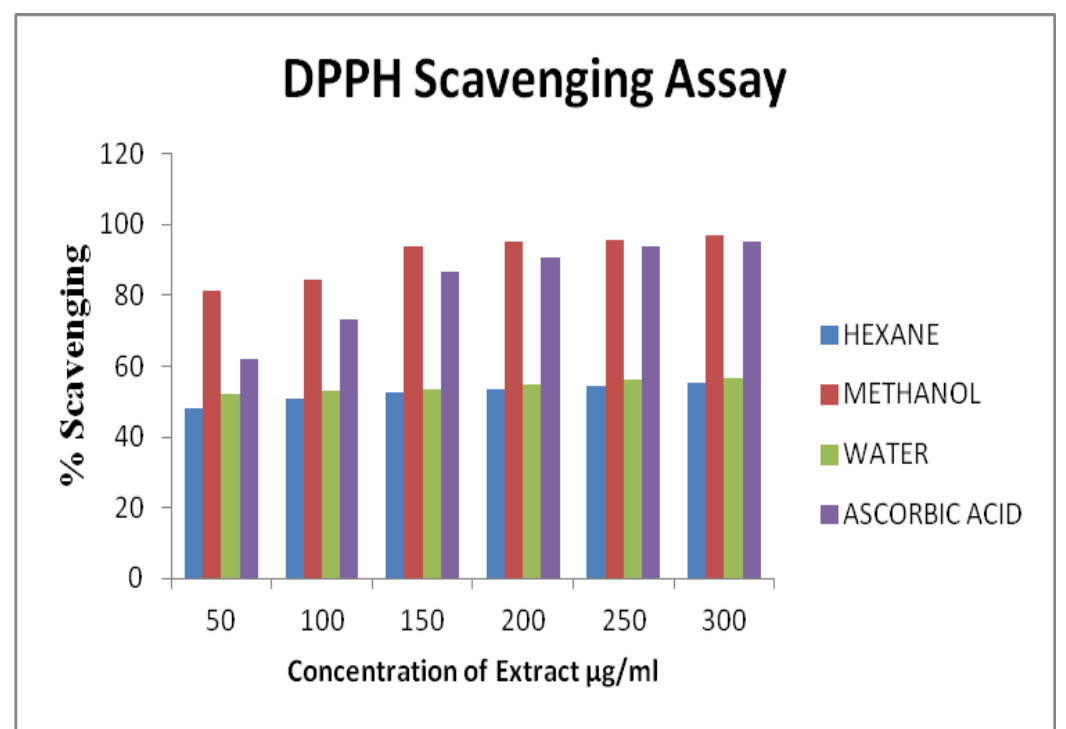

Fig 1:-DPPH radical scavenging assay of hexane, methanolic and water extract of Amorphophallus sylvaticus

\section{Nitric Oxide Radical Scavenging}

Nitric oxide radical scavenging property of Amorphophallus sylvaticus tuber extracts are shown in Fig.2. Nitric oxide radical inhibition study proved that the extract is a potent scavenger of nitric oxide generated from sodium nitroprusside which reacts with oxygen to form nitrite. The extract inhibits nitrite formation by competing with oxygen to react with nitric oxide directly and also to inhibit its synthesis. Scavengers of nitric oxide compete with oxygen leading to reduced production of nitric oxide. The scavenging of nitric oxide by the three extracts in a dose dependent manner shows the antioxidant activities of hexane, methanol and water extracts of Amorphophallus sylvaticus. $50-500 \mu \mathrm{g} / \mathrm{ml}$ of methanol extracts produces moderate to high nitric oxide radical scavenging. The percentage of inhibition has been increased with the increasing concentration of extract. The graph given below shows the nitric oxide scavenging activity of various extracts. Methanolic extracts shows highest percentage of inhibition which is $92.0 \%$ at concentration of $300 \mu \mathrm{g} / \mathrm{ml}$ and the lowest inhibition is exhibited by the hexane extract in contrast to standard reading,

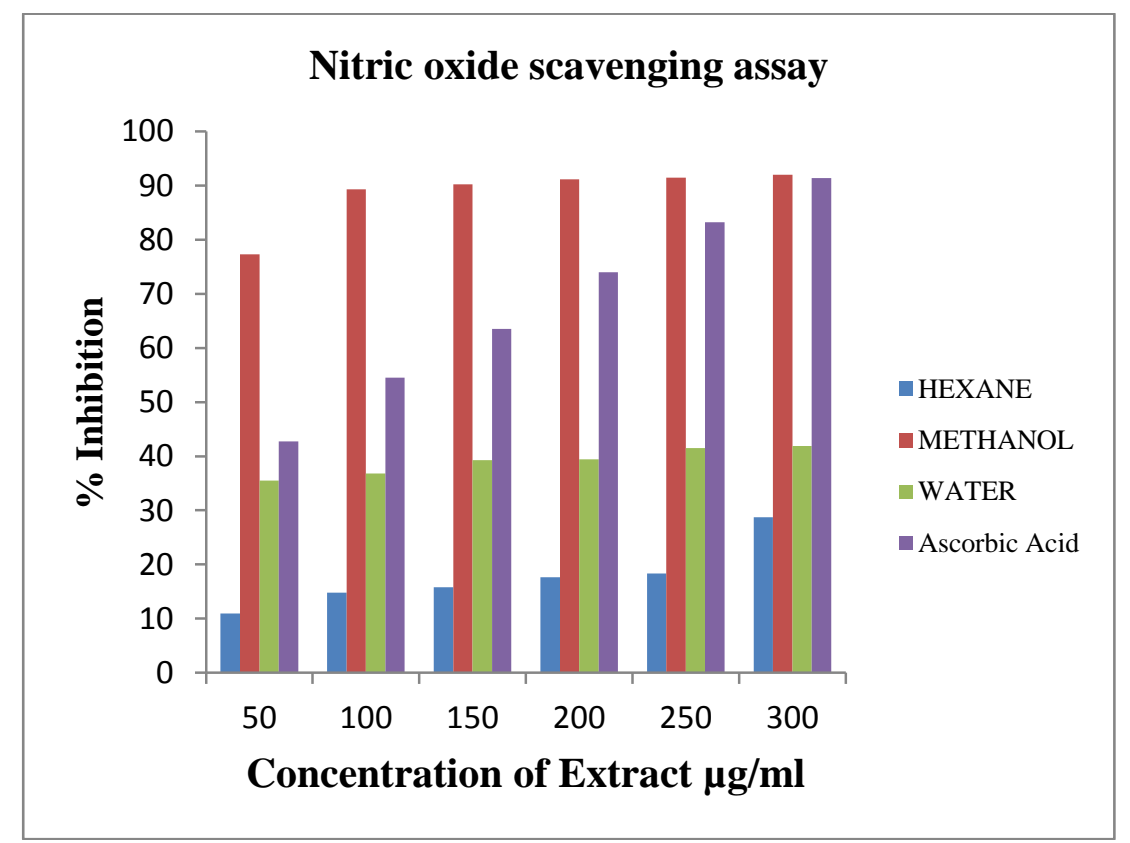

Fig 2:-Nitric oxide radical scavenging assay of hexane methanolic and water extract of Amorphophallus sylvaticus 


\section{Antibacterial Activity}

Agar well diffusion method is the widely accepted method for the evaluation of antibacterial activity of samples. Preliminary screening for the antibacterial activity of the extracts was performed with various strains of gram +ve and gram -ve pathogenic bacterial strains. Among the three extracts, methanolic extracts of Amorphophallus sylvaticus showed potent inhibition. The extract of Amorphophallus sylvaticus tested for antibacterial activity on nine bacterial strains are shown in Table 2. The zone of inhibition impregnated with plant extract over the lawn of bacterial culture plates determined the antibacterial activity. The result showed that the methanol extract showed highest antibacterial activity of $(20 \mathrm{~mm})$ inhibition zone against $L$. monocytogenes followed by hexane extract which show zone of inhibition $(18 \mathrm{~mm})$ against E-coli, smallest zone of inhibition of $(11 \mathrm{~mm})$ is shown by water extract against Bacillus Cereus. The zone of inhibition of various bacterial strains has been shown in Table 2 .

Table 2:-Zone of inhibition (in mm) of antibacterial activity of Amorphophallus sylvaticus in different extracts.

\begin{tabular}{|l|l|l|l|l|}
\hline Bacterial strains & Kenamycin & $\begin{array}{l}\text { Water } \\
\text { extract }\end{array}$ & $\begin{array}{l}\text { Methanol } \\
\text { exrtact }\end{array}$ & $\begin{array}{l}\text { Hexane } \\
\text { extract }\end{array}$ \\
\hline B.coagulans & 19 & - & 12 & 17 \\
\hline E-coli & 18 & 17 & 17 & 18 \\
\hline L.monocytogenes & 14 & 16 & 20 & - \\
\hline B. cereus & 18 & 11 & 14 & - \\
\hline S.fecalis & 15 & 14 & 14 & - \\
\hline S.aureus & 15 & 16 & 16 & - \\
\hline S. typhi & 12 & 17 & - & 14 \\
\hline B.circulans & 13 & 13 & 17 & - \\
\hline S.epidermis & 17 & - & - & 12 \\
\hline
\end{tabular}

\section{MIC}

Most potential extracts are selected for MIC determination based on the antibacterial activity results, i.e., water extract of Amorphophallus sylvaticus was tested against Salmonella typhi, hexane extract of Amorphophallus sylvaticus was tested against E. coli, methanol extract of Amorphophallus sylvaticus was tested against $L$. monocytogenes. The MIC corresponds to the highest concentration where no turbidity is observed, which corresponds to an inhibition of bacterial growth. By analyzing the different bacterial strains on a particular extract of Amorphophallus sylvaticus, the MIC value in each extract are methanol $-0.156 \mathrm{mg} / \mathrm{l}$, water $-0.625 \mathrm{mg} / \mathrm{l}$ and hexane$0.312 \mathrm{mg} / \mathrm{l}$. From these results it can be concluded that methanol extract of Amorphophallus sylvaticus has the best antibacterial potential because it inhibits the bacterial growth at lowest concentration. The results of this study also provided an insight into the antibacterial properties of the extracts used traditionally for the prevention and as treatments as well as opportunity for selection of bioactive extracts for initial fractionation and further studies in antibacterial assays.

\section{Discussion:-}

The phytochemical screening revealed the presence of many chemical constituents like phenols, flavonoids, alkaloids etc. in different extracts that form the foundation of their pharmacological activity (Table1). Studies conducted earlier in Amorphophallus paeoniifolius and Amorphophallus commutatus varities also revealed the presence of such secondary metabolites. The present study also confirms the presence of such secondary metabolites in Amorphophallus sylavaticus tuber and phenolics and flavonoids that possess antioxidant activity were found in Amorphophallus sylvaticus too. The different extract showed good radical scavenging properties on par with standard in DPPH and Nitric Oxide radical scavenging assessment. Free radicals are molecules or atoms that have at least one unpaired electron which usually increases the chemical reactivity of the molecule. Free radicals can react with other molecules to cause cell damage or DNA mutation. Molecules called antioxidants protect against free radical damage and their action permit to ensure a balance between production and destruction of free radicals. Antioxidant capacity of the methanolic, hexane and water extracts of Amorphophallus sylvaticus tuber evaluated by several antioxidant assays revealed that methanolic extract exhibited good antioxidant potential. Antimicrobial study also proved that Amorphophallus sylvaticus can be used against pathogenic bacteria's which substantiate the traditional use of the species for various ailments. Therefore, Amorphophallus sylvaticus can be considered as a natural source of antibacterial and antioxidants and may be considered in future to be used as antioxidant additive or as nutritional supplement and in cosmetic and pharmaceutical products with further detailed studies. 


\section{Acknowledgements:-}

We thank the management of VIT University, Vellore, Tamil Nadu for extending the lab facilities of School of Bio Sciences and Technology and Principal, Sir Syed College, Taliparamba, Kannur, Kerala for providing the facilities for performing the experiments. First author expresses his gratitude to The Commissioner, Navodaya Vidyalaya Samiti, Noida for permitting him to undertake the study and for the encouragement.

\section{References: -}

1. Abdul Jaleel V., M. Sivadasan, Ahmed H. Alfarhan, Jacob Thomas and A.A. Alatar (2011): Revision of Amorphophallus Blume ex Decne.sect. Raphiophallus (Schott)Engl. (Araceae)in India. Bangladesh Journal of Plant Taxon.,18(1):1-26

2. Arjun R. Krishna, Asis Singh, V.Abdul Jaleel, Sreena Raj, S.Karthikeyan, and K.M. Gothandam (2013): Morphological, Phytochemical and Antibacterial propertites of wild and indigenous plant (Amorphophallus commutatus)., Journal of Medicinal Plant Research. Vol.7(13) 744-748.

3. Ayfer A.D, Turgay Z.E (2003): Antimicrobial activities of various medicinal and commercial plant extracts., Turk. J. Biol. 27:157-162.

4. Ayvaz A, Osman S, Salih K, Ismet O (2008): Insecticidal activity of the essential oils from different plants against three stored product insect. J. Insect Sci. 10:1-13.

5. Bradshaw L.J (1992): Laboratory Microbiology, 4 th ed. Saunders College Publishing. Fort Worth, USA. P 435.

6. Edeoga H.O, Okwu D.E, Mbaebie B.O (2005): Phytochemical constituents of some Nigerian medicinal plants., Afr. J. Biotechnol. 4(7): 685-688.

7. Firdouse S, Alam P (2011): Phytochemical investigation of extract of Amorphophallus campanulatus tubers. Int. J. Phytomed., 3(1):32-35.

8. Gennaro L, Sukhdev S.H., Suman Preet S, Khanuja, Dev Dutt R. (2008): Extraction Technologies for Medicinal and Aromatic Plants. United Nations Industrial Development Organization and the International Centre for Science and High Technology, Trieste, Italy. P 23.

9. Hetterscheid W. L. A, and Ittenbach S. (1996): Everything you always wanted to know about Amorphophallus, but were afraid to stick your nose into., Aroideana ,19:7-131.

10. Jain A, Katewa S.S, Galav P.K, Sharma P (2005): Medicinal plant diversity of Sitamata wild life sanctuary, Rajasthan, India. J. Ethnopharmacol. 102:143-157.

11. Jyothi D. Vora, Ms. Aswathi Sarman, M.S. Nonita Madhrani (2015): Biochemical, Organoleptic and Antimicrobial Assessment of Elephant Foot yam (Amorphophallus paeonifolius). Journal of Environmental Science, Toxicology and Food Technology., Vol.9(5) Ver.1: 7-10.

12. Kavitha K.R, Karthikeyani S, Krishna K.S (2011): Anti-bacterial activity of Amorphophallus commutatus, an endemic plant of Western Ghats, South India., J. Pharm. Res. 4(3):710-711.

13. Kavitha Krishna R, S. Krishna Kumar, M. Vinodha, Anu Sebastian, and R. Gomathi (2012): Invitro free radical scavenging activity of Amorphophallus commutatus an endemic aroid of Western Ghats, South India., International research journal of pharmacy; 3(2) 133-137.

14. Lopez-Brea M, Alarcon T, Domingo D, Diaz Reganon J (2008): Inhibitory effect of Gram negative and grampositive microorganism against Helicobactor pylori clinical isolates., J. Antimicrob.Chemother.61:139-142.

15. Madhurima P, I.J. Kuppsat, K.L.Mankani (2012): A review on Amorphophallus paeoniifolius. International Journal of Advanced scientific research and Technology., Vol (2): 99-111.

16. Maina S.M, Emongor Q, Sharma, K.K, Gichuki S.T., Gathaara M, de Villiers S.M (2010): Surface sterilant effect on the regeneration efficiency from cotyledon explants of groundnut (Arachis hypogea L.) varieties adapted to Eastern and Southern Africa. Afr. J. Biotechnol, 9(20): 2866-2871.

17. Manju Madhavan and Regi Raphel (2012): Pharmacognostic and preliminary Phytochemical Screening of the corm Amorphophallus paeoniifolius (Dennst)Nicols.var.paeoniifolius. Academic Sciences vol.4, suppl 5:238240.

18. Onkar D, Dhingra J.B (1995): Basic plant pathology methods., 2 nd edition. Lewis Publishers, Boca Raton. pp. 287-305.

19. Ravikumar K, Ved D.K (2004): Illustrated Field Guide- 100 Red listed medicinal plants of conservation concern in South India., FRLHT, Bangalore., pp. 1- 467.

20. Revathi,E and G.Rani(2014): Antimicrobial potential activity of Amorphophallus sylvaticus Extract against Oral micro organisms., IJIPBART,Vol 1(1): pp 38-46 
21. Sagarika Damle and Atul Kotian (2015): Elemental, Phytochemical and Antibacterial analysis of Amorphophallus commutatus Lnn., International Journal of Recent Scientific Research Vol.6, Issue 5: 43084311.

22. Shete C.C., Wadkar S.S., Gaikwad N.B., Patil K.S. and Ghosh J.S (2015): Phenolic content and antioxidant capacity of Amorphophallus commutatus and Amorphophallus paeoniifolius., International Food Research Journal 22(5): 1939-1944.

23. Trease G.E, Evans W.C (1978): A Text book of Pharmacognosy, 11th edition. Bailliere Tindall London. P 530.

24. Yadu Nabdan Dey, Sarada Ota, N. Srikant, Mahvish Jamal and Manish Wanjari (2012): A phytochemical review of on an important medicinal plant Amorphophallus paeoniifolius., Ayu.2012: 33(1):27-32.

25. Yadu Nandan Dey and Ajoy Kumar Ghosh (2010): Pharmacognostic and Phytochemical analysis of the tuber Amorphophallus paeonifolius. Indian Journal of Pharma. Research and Development., IJPRD Vol.2.Issue-9 44- 49.

26. Yusuf M., Chowdhury J.U., Yahab M.A. and Begum J (1994): Medicinal Plants of Bangladesh, p-2, Dhaka, BCSIR Laboratories. 